\title{
Brief Summary of the "Pedagogical Poem A.S. Makarenko": Social and Pedagogical Analysis
}

\author{
Nesterov Artem Yurevich* \\ Candidate of Sociological Sciences, Lecturer of Moscow State University technologies and management of the \\ name of K.G. Razumovsky, Russia
}

*Corresponding Author: Nesterov Artem Yurevich, Candidate of Sociological Sciences, Lecturer of Moscow State University technologies and management of the name of K. G. Razumovsky, Russia

\begin{abstract}
Educational process is, first of all, a process that lasts continuously, and its individual details are resolved in the general tone of the family, and the general tone can not be invented and artificially maintained. The general tone, dear parents, is created by your own life and your own behavior.
\end{abstract}

\section{A.S. Makarenko}

Annotation: The author of the publication analyzes the methods and pedagogical experience of the outstanding teacher A.S. Makarenko. Methods of educational influence in the system of boarding schools of the USSR are given.

Keywords: A.S. Makarenko, Essence and methods of bringing up children of street children, socialization, resocialization, homeless children.

\section{INTRODUCTION}

Great interest of the great writer to the intention to create a book about the pedagogical experiment was explained, according to A.S. Makarenko, by the fact that M. Gorky was vividly "interested in the new positions of man on earth, new ways of trusting people and new principles of social creative discipline". A pedagogical poem tells how, in the children's colony created in the first years after the Civil War, the formation of a "real man" from among homeless, petty thieves, people, crippled by the difficult and cruel conditions of the civil war, was going on.

Theoretical heritage of A.S. Makarenko, his convictions and brilliant talent, which were fully developed in the 1920s and 1930s, still, to be sure, serve the school, enrich our ideological and creative life. Time does not extinguish, but opens up more and more facets of his selfless and versatile pedagogical work, he experienced 200,000 hours of working tension - those precious hours during which more than 3000 children and teenagers passed through his hands.

"Pedagogical Poem" A.S. Makarenko gave 10 years of hard work. One of the most important events in the history of the creation of this remarkable book is the visit to A.M. Gorky colony, which led the A.S. Makarenko. Great interest of the great writer to the intention to create a book about the pedagogical experiment was explained, according to A.S. Makarenko, by the fact that M. Gorky was vividly "interested in the new positions of man on earth, new ways of trusting people and new principles of social creative discipline".

"Pedagogical Poem", tells how in the children's labor colony, created in the first years after the Civil War (1920s), there was the formation of a "real man" from the number of homeless, petty thieves, people crippled by the difficult and brutal conditions of the civil war. Creation of a team that is excellent in terms of its ideological and moral qualities is shown in the "Poem" widely and "multifaceted".

In the work on the book, A. Makarenko, there were ups and periods of disbelief in success. It used to be that the finished chapters seemed not an artwork, but a "book on pedagogy" written in the form of memoirs. The belief in the writer was inspired by M. Gorky - the first reader and editor of the "Pedagogical Poem". He wrote: "In my opinion, the" Poem "was very successful for you, Anton Semenovich. Not to mention the importance of her story, about the most interesting material, you 
managed to develop this material very successfully and found a true, lively and sincere tone of the story, in which your humor is appropriate, as much as possible".

Analytics: "Poem" consists of three parts. It is based on a chronological description of the formation and development of a very complex educational institution that has traversed the anarchism of "homelessness" and "philistine individualism" to the militant, effervescent Soviet reality, illuminated by the norms of the socialist community.

A distinctive feature of the "Poem" is the masterful combination of artistic narrative, theoretical struggle in the pedagogy of the 1930s and journalism. Subtle artistic taste of A.S. Makarenko did not allow the book to be overloaded with details of everyday life and details of pedagogical searches. He focuses the reader's attention on the facts and events that ultimately determined the system of educating the collective of "colonists" and very vividly revealed the essence of humanistic pedagogy, and the author himself was nominated among the best "invaders" of her "fighting spirit". The moral and aesthetic ideal of the author of the poem finds the most complete expression in respect for man and in his high demands on him, in the poetization of creative work.

A.S. Makarenko was a very gifted man. His teaching career began at a time when, along with talent, life example, civil pathos, moral and ideological purposefulness and the highest selflessness were of particular importance. These qualities enabled him to achieve brilliant success in the struggle for the education of a new man. Poetry teacher A.S. Makarenko nourished his desire to transfer to the pupils all the wealth of a new worldview, to please them with new perspectives, thoughts and feelings, to make them better and winged. The main thing in his work is not the "taming" of a wild family of street children, but the formation of a children's collective, the formation of the personality of a new person. The poetry of his human and teacher's deeds, the poetry of comprehension and transformation of the lives of his pupils, logically resulted in the "Pedagogical Poem" - one of the most amazing and read books of world literature.

The secret of the eternal youth of the Poem is the author's deep penetration into the social problems of his time, in his active love for street children. In a bold statement of the question of style, tone, organizational forms and means of Soviet education, the author managed to say his own not very large, but necessary truth.

As a word artist, A.S. Makarenko deeply felt the socio-economic changes in our Soviet society. As a teacher, A.S. Makarenko prospectively and boldly paved the way for a new Soviet system of education. Now all the greatness of the exploit of the teacher-innovator (A.S. Makarenko) is clearly visible. This experience required approbation of time. Time has shown that the teacher and the artist still teaches us to think big, responsibly and specifically approach every pedagogical phenomenon.

The pedagogical skill was for A.S. Makarenko's moral necessity. After all, at the heart of everything he did was a relentless, uncompromising, jubilant and militant struggle for man, for his tomorrow's joy. The lasting value of the "Pedagogical Poem" is that it is illuminated by the romance of this struggle, filled with the light of wisdom and the unfading beauty of pedagogical work ${ }^{1}$.

II

Basic ideas and unique practical experience A.C. Makarenko in the education of adolescents, especially difficult, find a response among many teachers of different countries of the World right up to our days. World Glory A.C. Makarenko is associated with the effectiveness of his pedagogical activity, primarily in the elimination of child neglect. Thanks to this wonderful teacher, thousands of children who were doomed to a miserable existence, took place in life, and many of them became outstanding teachers and scientists of the USSR.

With his practice, he confirmed his words: «I confess an infinite, confidence in the unlimited power of educational work ... I do not know of any cases when a full-fledged character arose without a healthy educational environment, or, conversely, when the character warped would have turned out, despite the correct educational work» [Makarenko, 1987].

A.S. Makarenko found the most powerful lever of upbringing - he acted through the creation of a team faced with responsible tasks. System of education A.C. Makarenko - this is based on three interrelated principles:

\footnotetext{
${ }^{1}$ See:A short story of the "Pedagogical Poem" by A.S. Makarenko. [Electronic resource] / access mode: :http:// www.litrasoch.ru/kratkij-syuzhet-pedagogicheskoj-poemy-makarenko/(date of circulation: March 22, 2013).
} 
- Work on which the real well-being of children depends (quality of nutrition, clothing, entertainment, excursions, etc.). [At the same time, pupils should have the opportunity to choose, so that everyone can find a job to their liking. It is of fundamental importance that the children themselves dispose of the fruits of their labor];

- Self-government;

- Collective responsibility. [For the misdeed of one is the responsibility of the whole group].

A.S. Makarenko noted that, - "... unusually fast, in a matter of months, difficult teenagers are reeducated. They have an awareness of the boundaries of their powers and responsibilities".

At the same time, he wrote that education is a long process, both in general and in its separate parts. The militarized nature of upbringing in an educational labor colony was dictated by the fact that such an entourage was attractive to teenagers of that time. Pedagogical discipline was expressed in its strict observance, since the children themselves were interested in it. Neither of the punishments used in the colony was humiliating. The most severe in the children's collective is a boycott, which was used extremely rarely.

\section{A.S. Makarenko "On Education":}

- "Our children are always citizens. And the more civic duty is associated with their growth and upbringing, the more fully the people are raised from them";

- "I do not believe that there are morally defective people. It is only necessary to put it in normal conditions of life, present certain requirements to it, enable it to fulfill these requirements, and it will become an ordinary person, a full-fledged person, a man of norm";

- "I repeat that if a hooligan emerges from a person, then it is not he who is to blame, but pedagogical methods are to blame";

- "I have the right to argue that work on education is a very easy job. Easy not in the sense that you can work, then go for a walk, then read, rest, etc. No, it takes a lot of time, but it's light in type of tension"2.

A.S. Makarenko, "In recent years I've had 600 communards ... and it was easy for me to work, so easily that since 1930 I worked without an ordinary tutor in a boarding school. There were teachers in the school, there were engineers at the plant, but the children's collective of 600 people lived, in a certain sense, independently. And, in the morning, when I heard the signal to "get up" and knew that there was not a single adult in my team, I was not worried". "... At first I was amazed, knowing how difficult it is to get up on time, to rub the floors when nobody follows you, and then stopped being surprised and saw that this is a normal collective action, a normal human act, and a normal human act is the simplest and most easy act" ${ }^{\prime \prime}$.

A.S. Makarenko "About the team":

- "With the normal organization of the children's collective, it will always look like a miracle. At us in the Soviet school often hooligan in 5-6 class, in 10 class study, and then become students and pilots. How many hooligans? No one! And how many shouted that there were hooligans in the school?!";

- "The collective is the educator of the person";

- "I came to a deep conviction that there is no direct transition from the whole collective to the individual, but there is only a transition through the primary collective, specially organized for pedagogical purposes";

- "Any, even a small, joy, facing the team ahead, makes it stronger, friendly, cheerful";

- "To preserve the collective, keep its living core, make sure that the generation is always replaced when there is a prepared generation, save the rules, traditions";

\footnotetext{
${ }^{2}$ See: Memoirs of A.S. Makarenko, his works in the WTC and on the "Poem". Collection of Materials, L., 1958, pp. 40-43.

${ }^{3}$ See: A. Makarenko. Pedagogical Poem / Comp., Intro.article, note, comment. S.S. The Nevskaya. - M .: ITRK, $2003-736 \mathrm{p}$.
} 
- "Where educators are not connected to the collective and the collective does not have a single work plan, a single tone, a single exact approach, there can not be any educational process there";

- "In no case should the regime be held together by drill. The ranks, the team, the military subordination, the marching along the building are all the least useful forms in the working children's and youth team, and they not only strengthen the collective, but tire the children physically and mentally" 4 .

\section{A.S. Makarenko "On Punishment":}

- "Punishment is not only a right, but also a duty in cases where punishment is necessary";

- "Punishment should be imposed only if the interests of the collective are violated and if the violator is openly and consciously going to this violation, neglecting the demands of the collective";

- "Is a stroke a method? It's just despair!";

- "I consider such punishments, which express simultaneously respect for and demand for a person, as possible, when they are applied, skillfully, and in general I did not have to apply punishments on a large scale"5.

A.S. Makarenko "About the family":"The educational process is a continuous process, and its individual details are resolved in the general tone of the family, and the general tone can not be invented and artificially maintained. The general tone, dear parents, is created by your own life and your own behavior".

A.S. Makarenko "About work": "Work without a nearby education, without a political and public education that is going on alongside, does not bring educational benefit, turns out to be a neutral process. You can make a person work as much as you like, but if at the same time you do not educate him politically and morally, if he does not participate in public and political life, then this work will be just a neutral process, not giving a positive result" ${ }^{\prime \prime}$.

\section{REFERENCES}

[1] Balabanovich, E.Z. Anton Semenovich Makarenko is a man and a writer. Moscow: Moscow Worker, 1963. - $470 \mathrm{p}$.

[2] Memories of A.S. Makarenko. Collection of materials, - L.: Lenizdat, 1960. - 437 p.

[3] Gorky M., On the Union of Soviets, Collected Works in 30 vols., Vol. 17, - M .: Gikhl, 1952. P.38-87.

[4] Makarenko A.S. Pedagogical Poem / Comp., Intro. article, note, comment. S.S. The Nevskaya. - M .: ITRK, 2003 - 736 pp.

[5] Makarenko A.S. Collected Works in 4 vols. Volume 4. - M .: True, 1987. - 557 p.

[6] Makarenko AS Pedagogical essays in 8 t: T. 5. / Comp: L. Yu. Gordin, A.A. Frolov. - M .: Pedagogy, 1985. - $336 \mathrm{p}$.

[7] Makarenko A.S. Collected Works in 5 vols. Volume 3. - M .: True, 1971. P.21-78.

[8] Russian Soviet writers. Prose writers. Bibliographic index. Volume 2. / Zadornov - Lyashko. - M., 1964. $676 \mathrm{p}$.

(C) A. Nesterov, 2018

Citation: Nesterov Artem Yurevich. "Brief Summary of the "Pedagogical Poem A.S. Makarenko": Social and Pedagogical Analysis" International Journal of Research in Sociology and Anthropology (IJRSA), vol 4, no. 1, 2018, pp. 36-39. doi:http://dx.doi.org/10.20431/2454-8677.0401005.

Copyright: (c) 2018 Authors. This is an open-access article distributed under the terms of the Creative Commons Attribution License, which permits unrestricted use, distribution, and reproduction in any medium, provided the original author and source are credited.

\footnotetext{
${ }^{4}$ See: Collected Works, vol. 1-7, 2 ed., Moscow, 1959 - 60 p.

${ }^{5}$ See: Ibid.

${ }^{6}$ See: A. Makarenko. Pedagogical Poem / Comp., Intro.article, note, comment. S.S.The Nevskaya. - M .: ITRK, 2003 - 736 pp., Ill .; Photo 2 - Pupil of the labor colony of M. Gorky. [Electronic resource] / access mode: http://vp-ch.ru/node/9; http://vp-ch.ru/node/37 (reference date: March 22, 2013).
} 